\title{
NOTES
}

\section{WHITMAN TO C. W. POST: A LOST LETTER LOCATED}

In the standard edition of Whitman's extant correspondence, his letter to C. W. Post is noted only in the "Check List of Whitman's Lost Letters" as having been dated February $8,1880 .{ }^{1}$ The letter was not included in the first or second supplementary volumes of extant correspondence, ${ }^{2}$ and its contents have remained unknown. Our information on it comes from the published edition of Whitman's daybooks: the poet glued Post's address into an 1879 travel notebook, but, according to William White, "Whitman's letter to Charles W. Post, 8 February, 1880, and Post's letter to Whitman, about 8 May 1880, are both lost." 3

The holograph letter from Whitman is, in fact, held in a private repository which opened to the public in 1977. Here is the full text:

431 Stevens Street Camden New Jersey

Feb. 8 ' 80

\section{Dear Young Man}

I thought to-day I would send you a little picture to show you I had not forgotten you or those meetings in St Louis-I have been back here about a month, \& am tolerably well-How are you getting along? Let me know if you get the picture all right

Walt Whitman

The envelope, written in Whitman's hand, accompanies the letter. It is addressed to

\author{
Charles W Post \\ Care of B D Buford \& Co: \\ Kansas City \\ Missouri
}

and bears a postmark for "Feb. 8, '80" with part of the cancellation from Camden. Also retained is the signed and dated ("1880") photograph of Whitman, which is actually an 1878 image by Napoleon Sarony. ${ }^{4}$

Six years after his first stroke, at the age of 61 , Whitman apparently met the 25-year-old C.W. Post on the return lap of the poet's autumn, 1879, western trip. On this journey, Whitman had stopped in St. Louis only briefly while going west, but on returning from Denver, he "went on to St. Louis where I remain'd nearly three months with my brother T.J.W. [Thomas Jefferson Whitman], and my dear nieces." While recouping his failing health, he nevertheless made many social appearances which are detailed by Robert 
Hubach, Gay Wilson Allen, and Walter Eitner, ${ }^{6}$ among others. These literary historians, however, make no mention of Whitman's acquaintance with Post during that period.

Post's biographer, however, does quote the letter as an example of C.W. Post's "ability to make warm friends upon casual meeting."7 At the time he met Whitman, Charles William Post (1854-1914) was a married traveling salesman from Springfield, Illinois. He sold agricultural implements for the B.D. Buford Company. Destined to become one of America's first multimillionaires, this pioneer manufacturer, market researcher, and advertising innovator went on to invent and sell the country's first commercial coffee substitute - the early health drink, Postum-and to develop the first dry packaged cereals. He is often credited as the originator of the prepared food industry.

When C.W. Post died in 1914, he left his vast wealth and corporate holdings to his daughter, Marjorie Merriweather Post, who administered them until her own death in 1973. Her dazzling collection of French and Russian decorative arts can be viewed, with prior reservation, at Hillwood Museum, Washington, D.C., on the tour of the main house of her former Washington residence. On this estate property is the C.W. Post Wing, which houses her father's smaller collection of primarily American art. In a back corner, surrounded by Gustav Stickly arts and crafts furniture, hangs the letter to C.W. Post from Walt Whitman.

Library of Congress, Washington, D.C.

Alice Lotvin Birney

\section{NOTES}

1 Walt Whitman, The Correspondence, ed. Edwin Haviland Miller (New York: New York University Press, 1964), 3:434.

2 The Correspondence, ed. Edwin Haviland Miller, Volume 6: A Supplement with a Composite Index (New York: New York University Press, 1977); The Correspondence of Walt Whitman: A Second Supplement with a Revised Calendar of Letters Written to Whitman, ed. Edwin Haviland Miller (Iowa City: Walt Whitman Quarterly Review Press, 1991).

3 Walt Whitman, Daybooks and Notebooks, ed. William White (New York: New York University Press, 1978), 1:157n, 168n, 171.

4 Walt Whitman Quarterly Review 4 (Fall/Winter 1986-87) [Special Double Issue: Whitman Photographs], 20, 51.

5 Specimen Days (Boston: Godine, 1971), 96.

6 Robert R. Hubach, "Walt Whitman Visits St. Louis, 1879," Missouri Historical Review 37 (July, 1943), 386-393; Gay Wilson Allen, The Solitary Singer (New York: Macmillan, 1955), 486-489; Walter H. Eitner, Walt Whitman's Western faunt (Lawrence: Regents Press of Kansas, 1981), 73-87.

7 Nettie Leitch Major, C. W. Post-The Hour and the Man (Washington, D.C.: Judd \& Detweiler, Inc., 1963), 12. 